Article

\title{
Diversity of Trichoderma spp. in Marine Environments and Their Biological Potential for Sustainable Industrial Applications
}

\author{
Kyeongwon Kim ${ }^{1}$, Young Mok Heo ${ }^{1} \mathbb{1}$, Seokyoon Jang ${ }^{1}$, Hanbyul Lee ${ }^{1}$, Sun-Lul Kwon ${ }^{1}$,

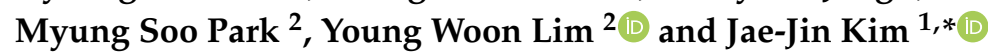 \\ 1 Division of Environmental Science \& Ecological Engineering, College of Life Science \& Biotechnology, Korea \\ University, Seoul 02841, Korea; rudndjs@korea.ac.kr (K.K.); hym011@korea.ac.kr (Y.M.H.); \\ skel@korea.ac.kr (S.J.); hblee95@korea.ac.kr (H.L.); sun-lul@korea.ac.kr (S.-L.K.) \\ 2 School of Biological Sciences and Institute of Microbiology, Seoul National University, Seoul 08826, Korea; \\ ms1014@snu.ac.kr (M.S.P.); ywlim@snu.ac.kr (Y.W.L.) \\ * Correspondence: jae-jinkim@korea.ac.kr; Tel.: +82-2-3290-3049
}

Received: 6 May 2020; Accepted: 21 May 2020; Published: 25 May 2020

\begin{abstract}
Microorganisms are regarded as a sustainable source of biologically active molecules. Among them, Trichoderma spp. have been an attractive source of biological compounds. However, the study of marine-derived Trichoderma has developed slowly because of the difficulty in isolating the fungi. In our study, 30 strains of marine-derived Trichoderma were identified through the translation elongation factor 1-alpha (EF1 $\alpha)$ sequences, and their biological activities, such as antioxidant activity by ABTS and DPPH assays, antifungal activity against Asteromyces cruciatus and Lindra thalassiae, and tyrosinase inhibition activity, were investigated. As a result, the 30 marine Trichoderma species were classified into 21 taxa, including three new species candidates. Three strains of T. asperellum showed the highest ABTS radical scavenging activity and antifungal activity. T. bissettii SFC20170821-M05 and T. guizhouense SFC20180619-M23 showed notable DPPH radical scavenging activity and tyrosinase inhibition activity, respectively. This study showed the potential of marine-derived Trichoderma as a source of bioactive compounds.
\end{abstract}

Keywords: antagonistic activity; biological control; phylogenetic analysis; radical scavenging; skin whitening agents

\section{Introduction}

In a specific environment, biodiversity is the most essential information for sustainable development and is important in discovering biological resources [1-6]. In particular, microorganisms have been considered as a sustainable source of various bioactive compounds as well as useful enzymes [7-14]. Traditional sources of natural products have been terrestrial plants, fungi, and bacteria. The idea of natural products from the ocean has recently been of interest, but the need for additional efforts, such as scuba diving or instruments for collecting or culture, have made the development of marine natural compounds slow in comparison with its terrestrial counterpart $[15,16]$. Nevertheless, the structural uniqueness and profound effect of marine-derived compounds have been of interest to the pharmaceutical and cosmetic industry [17,18]. A total of 200 million microorganisms in the ocean covering $71 \%$ of the surface of the earth have been presumed, although the exact number of microorganisms is still open to debate $[19,20]$. For this reason, marine organisms, especially microorganisms, have attracted the attention of the pharmaceutical and cosmetic industries as a new reservoir of novel natural compounds $[17,20]$. 
The genus Trichoderma is well known for its ability to produce antibiotic compounds and parasitize other fungi [21-23]. The actions of antifungal secondary metabolites (i.e., 6-pentyl- $\alpha$-pyrone and trichodermaketones) and cell wall hydrolytic enzymes (i.e., $\beta-1,3,-$ glucanases and $\beta-1,6,-$ glucanases) secreted by Trichoderma spp. can cause the death of prey [21,24-26]. Several Trichoderma provide a beneficial effect to host plants by activating plant defense mechanisms, preventing pathogen attacks and promoting plant growth [21,27]. To date, more than 250 species of the genus Trichoderma have been reported [28]. Approximately 78 metabolites have been described from marine-derived Trichoderma so far, and most of them showed a variety of industrially useful biological activities, such as antifungal, antibacterial, and antioxidant activity $[29,30]$. Reliable phylogenetic information is important to discover the diversity of secondary metabolites of microorganisms, and it is difficult to distinguish Trichoderma spp. by morphology alone, because they share many morphological features [31-33]. Thus, a molecular biological analysis is essential for the accurate identification of Trichoderma [34]. The internal described spacer (ITS) is the most universal fungal molecular barcode $[35,36]$. However, the ITS has low species resolution in the genus Trichoderma [32]. Instead of ITS, translation elongation factor 1-alpha $(E F 1 \alpha)$ sequences were recommended for phylogenetic analysis of this genus [32].

The aim of this study was to investigate the diversity of Trichoderma spp. in marine environment in South Korea using phylogenetic analysis and evaluate the marine Trichoderma spp. as a source of bioactive secondary metabolites by investigating the antifungal, antioxidant, and tyrosinase activities of the fungal extracts.

\section{Materials and Methods}

\subsection{Preparation of Trichoderma Cultures}

A total of 30 marine Trichoderma cultures were obtained from the Marine Fungal Resource Bank (http://mfrb.snu.ac.kr; Seoul, Korea). A list of the fungal species with their general information is shown in Table 1. Their sampling sites are indicated in Figure 1. They were subcultured on potato dextrose agar (PDA) media in room temperature: $20-25^{\circ} \mathrm{C}$.

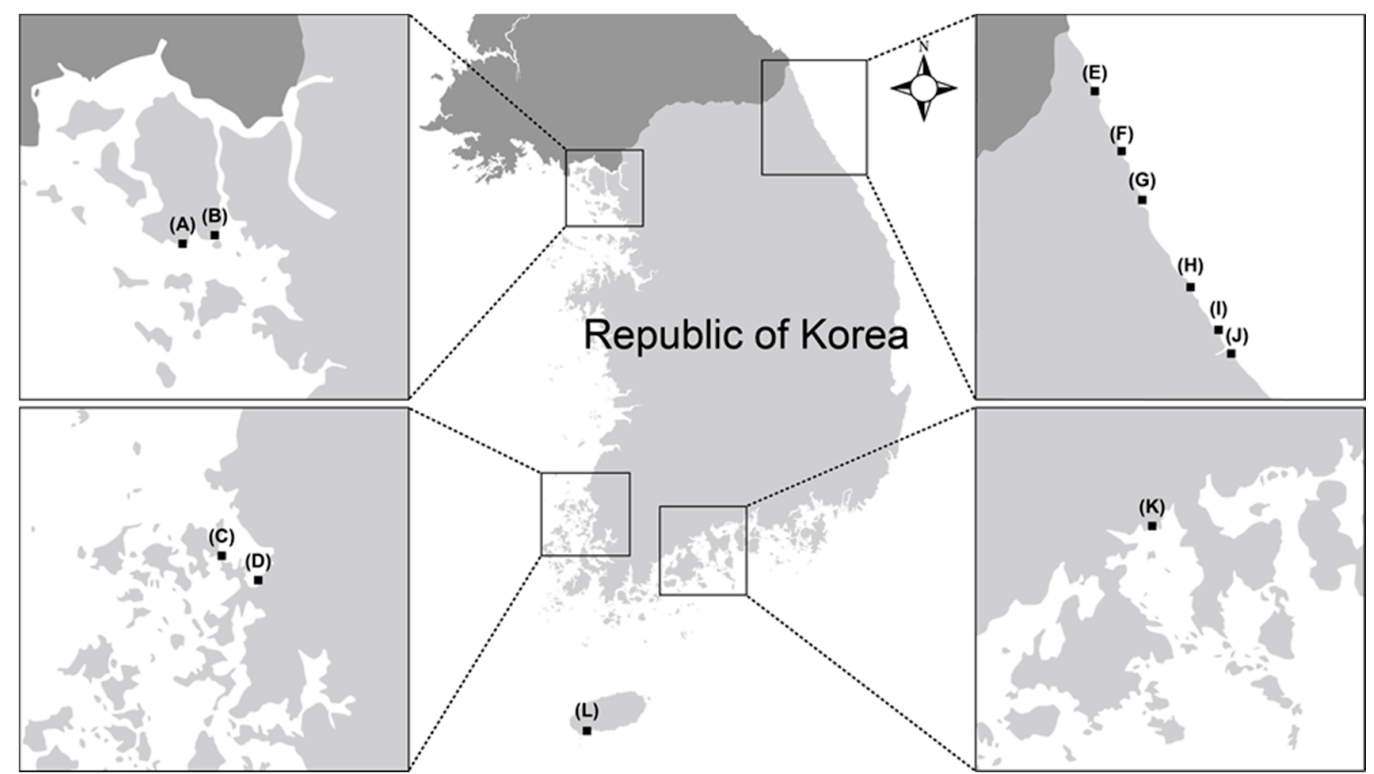

Figure 1. The map of sampling sites: (A) Hwado-myeon, and (B) Gilsang-myeon, Ganghwa-gun, Incheon; (C) seaside, and (D) mudflat in Hyeongyeong-myeon, Muan-gun, Jeollanam-do; (E) Hyeonnae-myeon, and (F) Jugwang-myeon Goseong-gun; (G) Sokcho Beach in Sokcho-si; (H) Hyeonnam-myeon, Yangyang-gun; and (I) Jumunjin-eup, and (J) Yeongok-myeon, Gangneung-si, Gangwon-do; (K) Byeollyang-myeon, Suncheon-si, Jeollanam-do; (L) Andeok-myeon, Seogwipo-si, Jeju-do, Korea. 
Table 1. General information of 30 marine-derived Trichoderma spp.

\begin{tabular}{|c|c|c|c|c|}
\hline Identity & ID & Sampling Date & Sampling SITE* & Isolation Source \\
\hline \multirow[t]{7}{*}{ Trichoderma afroharzianum } & SFC20160907-M20 & January 2015 & Hyeonnae-myeon, Goseong-gun, Gangwon-do E & Eggs of Arctoscopus japonicus \\
\hline & SFC20180619-M25 & January 2017 & Gilsang-myeon, Ganghwa-gun, Incheon B & Mudflat \\
\hline & SFC20190312-M15 & July 2016 & Gilsang-myeon, Ganghwa-gun, Incheon ${ }^{B}$ & Mudflat \\
\hline & SFC20180619-M20 & January 2015 & Hyeonnae-myeon, Goseong-gun, Gangwon-do E & Eggs of Arctoscopus japonicus \\
\hline & SFC20160907-M21 & January 2015 & Yeongok-myeon, Gangneung-si, Gangwon-do J & Eggs of Arctoscopus japonicus \\
\hline & SFC20180619-M22 & October 2016 & Hyeongyeong-myeon, Muan-gun, Jeollanam-do D & Mudflat \\
\hline & SFC20180619-M24 & October 2016 & Byeollyang-myeon, Suncheon-si, Jeollanam-do K & Sea sand \\
\hline T. atroviride & SFC20190312-M11 & January 2015 & Hyeonnae-myeon, Goseong-gun, Gangwon-do ${ }^{E}$ & Eggs of Arctoscopus japonicus \\
\hline T. atroviride & SFC20161110-M05 & December 2015 & Jugwang-myeon, Goseong-gun, Gangwon-do F & Agarum clathratum \\
\hline T. bissettii & SFC20170821-M05 & October 2016 & Byeollyang-myeon, Suncheon-si, Jeollanam-do K & Mudflat \\
\hline T. capillare & SFC20180619-M19 & January 2015 & Sokcho-si, Gangwon-do G & Eggs of Arctoscopus japonicus \\
\hline T. citrinoviride & SFC20180510-M16 & July 2016 & Hwado-myeon, Ganghwa-gun, Incheon A & Sea sand \\
\hline T. gamsii & SFC20160907-M22 & January 2015 & Yeongok-myeon, Gangneung-si, Gangwon-do J & Eggs of Arctoscopus japonicus \\
\hline \multirow[t]{4}{*}{ T. guizhouense } & SFC20160907-M23 & January 2015 & Yeongok-myeon, Gangneung-si, Gangwon-do J & Eggs of Arctoscopus japonicus \\
\hline & SFC20180619-M21 & August 2015 & Jumunjin-eup, Gangneung-si, Gangwon-do I & Agarum clathratum \\
\hline & SFC20180619-M23 & October 2016 & Hyeongyeong-myeon, Muan-gun, Jeollanam-do ${ }^{D}$ & Mudflat \\
\hline & SFC20190312-M12 & January 2017 & Andeok-myeon, Seogwipo-si, Jeju-do L & Sea sand \\
\hline T. hamatum & SFC20180510-M09 & July 2016 & Gilsang-myeon, Ganghwa-gun, Incheon ${ }^{B}$ & Mudflat \\
\hline T. longibrachiatum & SFC20171019-M03 & July 2016 & Gilsang-myeon, Ganghwa-gun, Incheon B & Mudflat \\
\hline T. orientalis & SFC20170718-M02 & January 2017 & Byeollyang-myeon, Suncheon-si, Jeollanam-do K & Mudflat \\
\hline T. paraviridescens & SFC20160907-M24 & January 2015 & Yeongok-myeon, Gangneung-si, Gangwon-do J & Eggs of Arctoscopus japonicus \\
\hline T. pyramidale & SFC20160907-M25 & January 2015 & Yeongok-myeon, Gangneung-si, Gangwon-do J & Eggs of Arctoscopus japonicus \\
\hline T. songyi & SFC20171120-M04 & October 2016 & Hyeongyeong-myeon, Muan-gun, Jeollanam-do ${ }^{C}$ & Sea sand \\
\hline T. subviride & SFC20170919-M07 & July 2016 & Andeok-myeon, Seogwipo-si, Jeju-do L & Sea sand \\
\hline T. virens & SFC20180817-M24 & October 2016 & Hyeongyeong-myeon, Muan-gun, Jeollanam-do D & Mudflat \\
\hline \multirow[t]{3}{*}{ Trichoderma sp. 1} & SFC20190312-M13 & January 2015 & Yeongok-myeon, Gangneung-si, Gangwon-do J & Eggs of Arctoscopus japonicus \\
\hline & SFC20190312-M14 & July 2016 & Gilsang-myeon, Ganghwa-gun, Incheon B & Mudflat \\
\hline & SFC20190312-M17 & November 2015 & Hyeonnam-myeon, Yangyang-gun, Gangwon-do $\mathrm{H}$ & Agarum clathratum \\
\hline Trichoderma sp. 2 & SFC20190312-M16 & October 2015 & Hyeonnam-myeon, Yangyang-gun, Gangwon-do $\mathrm{H}$ & Agarum clathratum \\
\hline Trichoderma sp. 3 & SFC20161110-M06 & September 2015 & Jumunjin-eup, Gangneung-si, Gangwon-do I & Agarum clathratum \\
\hline
\end{tabular}

* The sampling sites in Figure 1 were indicated by A-L. 


\subsection{Phylogenetic Analysis}

EF1 $\alpha$ sequences of marine Trichoderma were obtained from Marine Fungal Resource Bank. The closely related sequences for references were downloaded from GenBank using nucleotide BLAST. Type specimens were chosen for reference sequences except for Trichoderma virens. EF1 $\alpha$ sequence data of the CBS 249.59, type specimen of T. virens has only 200 bp in GenBank. Protocrea illinoensis GJS 94-54 (EU703904) was downloaded as outgroup of the genus Trichoderma. The obtained sequences were aligned using MAFFT 7.388 [37]. The aligned dataset was proofread and modified manually using MacClade 4.08 [38]. The aligned dataset contained 113 taxa and 752 characters. A neighbor joining tree was constructed with PAUP 4.0b10 [39]. The Kimura 2-parameter model was applied [40]. To indicate branch stability, 1000 replications of bootstrap analysis were carried out.

\subsection{Preparation of Fungal Extracts}

All of the fungal species were cultivated on $50 \mathrm{~mL}$ of PDA at $25^{\circ} \mathrm{C}$ for seven days in darkness. After 7 days of cultivation, the solid media were extracted with $200 \mathrm{~mL}$ of methanol for $24 \mathrm{~h}$. The methanol solution was filtrated with Whatman No. 1 filter paper. The filtrated solutions were evaporated at $37^{\circ} \mathrm{C}$ under a vacuum. The condensed residues were dissolved in $20 \mathrm{~mL}$ of ethyl acetate and $20 \mathrm{~mL}$ of distilled water. After $6 \mathrm{~h}$, the supernatant, the partitioned ethyl acetate fraction, was evaporated. The extracts were stored at $4{ }^{\circ} \mathrm{C}$. The fungal cultures were incubated in triplicate, and all the subsequent biological assays were performed in triplicate.

\subsection{Measurement of Antioxidant Activity by ABTS Scavenging Ability}

The 2.2'-azino-bis-3-ethylbenzothiazoline-6-sulfonic acid (ABTS, Sigma-Aldrich, Inc., St. Louis, $\mathrm{MO})$ solution dissolved in PBS $(7 \mathrm{mM})$ was oxidized with potassium persulfate $(2.45 \mathrm{mM})$ for $24 \mathrm{~h}$ in darkness at room temperature. The $\mathrm{ABTS}^{\bullet+}$ solution was diluted with PBS to an absorbance of $0.70( \pm 0.02)$ at a wavelength of $734 \mathrm{~nm}$. Then, $990 \mu \mathrm{L}$ of the $\mathrm{ABTS}^{\bullet+}$ solution and $10 \mu \mathrm{L}$ of each fungal extract sample (10 mg/mL in DMSO) were mixed in the cuvette and measured at $734 \mathrm{~nm}$ after $6 \mathrm{~min}$.

\subsection{Measurement of Antioxidant Activity by DPPH Radical Scavenging Ability}

The 2,2-diphenyl-1-picrylhydrazyl (DPPH) (Sigma-Aldrich Inc., St. Louis, MO, USA) was dissolved in methanol $(80 \%)$ at $150 \mu \mathrm{M}$. An aliquot $(22 \mu \mathrm{L})$ of the fungal extracts $(10 \mathrm{mg} / \mathrm{mL})$ were each mixed with $200 \mu \mathrm{L}$ of DPPH solution in the 96-well plate. The mixture was stored at room temperature for $30 \mathrm{~min}$ and measured at $520 \mathrm{~nm}$.

\subsection{Measurement of Antifungal Activities}

Asteromyces cruciatus SFC20161110-M19 was obtained from Marine Fungal Resource Bank (MFRB) at Seoul National University as a marine bioresource bank of Korea by the Ministry of Oceans and Fisheries, and Lindra thalassiae NBRC106646 was purchased from Biological Resource Center under National Institute of Technology and Evaluation. Asteromyces cruciatus SFC20161110-M19 and Lindra thalassiae NBRC106646 were tested as the target fungi and antifungal activity was determined in a 96-well plate. The $25 \mu \mathrm{L}$ of spore suspensions $\left(4 \times 10^{5}\right.$ conidia/mL) of the target fungi was added to each well containing $49 \mu \mathrm{L}$ of distilled water and $25 \mu \mathrm{L}$ of potato dextrose broth. The $2 \mu \mathrm{L}$ of Trichoderma extracts solubilized in dimethyl sulfoxide (DMSO) to a final concentration of $100 \mu \mathrm{g} / \mathrm{mL}$ was added to each well at the last. The 96 -well plates were incubated at $25^{\circ} \mathrm{C}$ for 3 days and the fungal growth was detected by measuring the absorbance at the wavelength of $595 \mathrm{~nm}$ [41]. The minimum inhibitory concentration (MIC) values were determined in the concentration range of $6.25-50 \mu \mathrm{g} / \mathrm{mL}$.

\subsection{Tyrosinase Inhibition Activity}

The assay was modified from the method described by Lai et al. [42]. An amount of $40 \mu \mathrm{L}$ of each fungal extract samples dissolved in 50\% DMSO at the same concentration $(2.5 \mathrm{mg} / \mathrm{mL}), 70 \mu \mathrm{L}$ 
of a $0.1 \mathrm{M}$ potassium phosphate buffer ( $\mathrm{pH} 6.8$ ), and $30 \mu \mathrm{L}$ of $0.02 \mathrm{mg} / \mathrm{mL}$ of tyrosinase were mixed in 96-well plate. The mixture was heated to $30{ }^{\circ} \mathrm{C}$ for $5 \mathrm{~min}$ and mixed with $100 \mu \mathrm{L}$ of $2.5 \mathrm{mM}$ L-dihydroxyphenylalanine (L-DOPA). After $30 \mathrm{~min}$, to terminate the reaction put the plate in the ice and the absorbance was measured at $492 \mathrm{~nm}$. Kojic acid was used as a positive control and all mixtures without L-DOPA was used as a blank.

\section{Results and Discussion}

\subsection{Identification and Phylogeny}

The marine Trichoderma were identified by phylogeny based on the EF1 $\alpha$ sequences (Figure 2). A tree containing 86 taxa of Trichoderma, including 83 known species and three new species candidates, was constructed. Among them, 25 of the sequences obtained were identified as eighteen previously reported species. Eleven of the sequences were grouped in the Harzianum clade: SFC20190312-M14, SFC20190312-M15, SFC20180619-M23, SFC20190312-M12, SFC20180619-M25, SFC20190312-M13, SFC20160907-M23, SFC20160907-M25, SFC20160907-M20, SFC20180619-M21, and SFC20190312-M17 [32,43]. The morphology of the tree was similar to that in other studies [32,43]. SFC20190312-M15, SFC20180619-M25, and SFC20160907-M20 were identified as T. afroharzianum with a high bootstrap value (100\%). SFC20180619-M23, SFC20190312-M12, SFC20160907-M23, and SFC20180619-M21 were grouped with T. guizhouense, but the bootstrap value was not very high (62.9\%). SFC20190312-M14, SFC20190312-M13, and SFC20190312-M17 had their own group without a close reference and were regarded as new species candidates. In this study, these cultures were named Trichoderma sp. 1. Their closest sister group contains T. afarasin, T. harzianum, and T. camerunense.

SFC20180817-M24 was placed in the Virens clade [43] and identified as T. virens (bootstrap value: 97.7\%). Its closely related species were T. crassum [43]. SFC20180510-M16, SFC20171019-M03, SFC20170821-M05, SFC20170718-M02, and SFC20160907-M2190 were placed in the Longibrachiatum clade [44,45]. SFC20171019-M03 was identified as T. longibrachiatum with high support (bootstrap value: 98.3\%). SFC20170718-M02 was grouped with T. orientale with a bootstrap value of $100 \%$. SFC20180510-M16 was identified as T. citrinoviride (bootstrap value: 100\%). SFC20160907-M2190 was grouped with T. capillare (bootstrap value: 100\%). Though SFC20170821-M05 was placed in a paraphyletic group with $T$. bissettii, it showed $100 \%$ similarity with the type specimens of $T$. bissettii based on a BLAST search. Thus, it was regarded as T. bissettii.

Eleven sequences were placed in the Viride clade: SFC20180510-M09, SFC20170919-M07, SFC20180619-M22, SFC20171120-M04, SFC20180619-M24, SFC20160907-M21, SFC20160907-M22, SFC20180619-M20, SFC20190312-M11, SFC20161110-M06, and SFC20161110-M05 [46-48]. Among them, SFC20160907-M22 was grouped with T. gamsii (bootstrap value: 100\%). SFC20190312-M11 was identified as T. paratroviride with a bootstrap value of 100\%. SFC20161110-M05 made a monophyletic group with T. atroviride (bootstrap value: 99.9\%). SFC20170919-M07 was placed in a monophyletic clade with high support (bootstrap value: 100\%). SFC20171120-M04 was grouped with T. songyi with a bootstrap value of $100 \%$. This species is known to be associated with Tricholoma matsutake [48]. SFC20180619-M22, SFC20180619-M24, and SFC20160907-M21 were in a monophyletic clade with T. asperellum (bootstrap value: 99.9\%). SFC20180619-M20 was identified as T. asperelloides (bootstrap value: 100\%). SFC20180510-M09, and SFC20161110-M06 were not assigned to a clade through close references; therefore, we regarded them as new species candidates. These cultures were named Trichoderma sp. 2 and 3, respectively. 


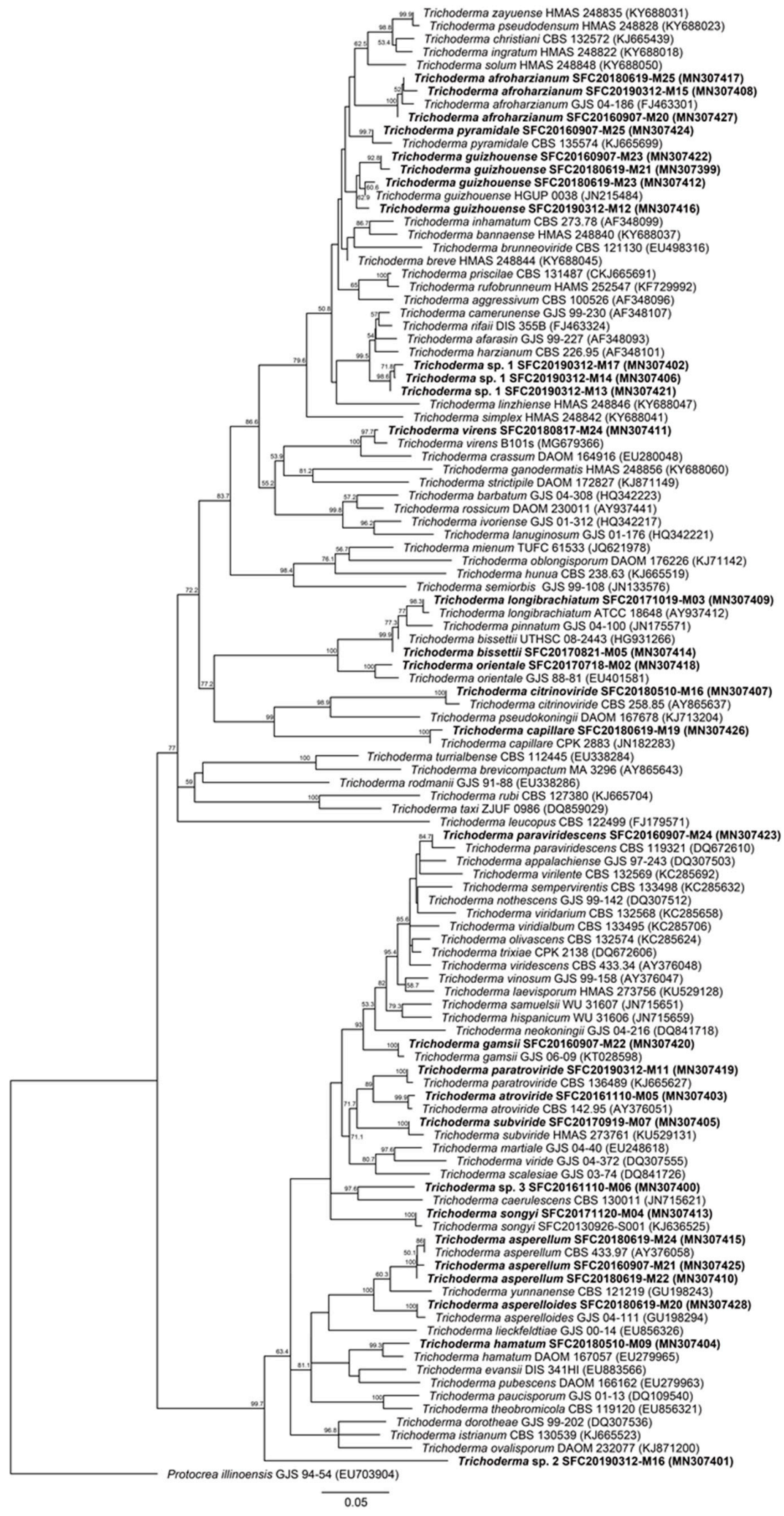

Figure 2. The neighbor joining tree of the EF-1 $\alpha$ sequences dataset. Numbers above branches indicate bootstrap values. Bootstrap values less than 50 were not shown. Fungal cultures collected in this study are in bold and colored. GenBank accession numbers are in parentheses. 


\subsection{Antioxidant Activity}

ABTS and DPPH radical scavenging assays were used to evaluate the antioxidant activity of 30 methanol crude fungal extracts of marine Trichoderma, and many of the marine Trichoderma extracts contained antioxidative compounds. Trichoderma asperellum SFC20160907-M21, SFC20180619-M22, and SFC20180619-M24 showed over 70\% ABTS radical scavenging activity, and T. bissettii SFC20170821-M05 and T. longibrachiatum SFC20171019-M03 exhibited over 70\% DPPH radical scavenging activity (Table 2). Other extracts showed lower inhibition rates from $2.3 \%$ to $69 \%$. Only four strains, T. bissettii SFC20170821-M05, Trichoderma sp. 1 SFC20190312-M13, T. longibrachiatum SFC20171019-M03, and T. subviride SFC20170919-M07, exhibited over 50\% antioxidant activities in both the ABTS and DPPH radical scavenging tests. Numerous studies have shown that various marine-derived natural compounds have radical scavenging properties that could be used as raw materials in the cosmetic and pharmaceutical industries $[18,49,50]$. For example, the major antioxidant in the food supplement Seanol is phlorotannins extracted from Ecklonia Cava [51]. Several natural compounds that have antioxidant ability, such as polyphenols and vitamins, also have other biological activities, such as antiaging and skin-whitening [52,53]. Some antioxidants have the ability to inhibit tyrosinase by eliminating reactive quinone products [52]. In this study, the extracts of T. atroviride SFC20161110-M05, T. gamsii SFC20160907-M22, T. guizhouense SFC20180619-M23, and T. songyi SFC20171120-M04, which showed a remarkable ability to inhibit tyrosinase $\left(\mathrm{IC}_{50}<100 \mu \mathrm{g} / \mathrm{mL}\right)$, exhibited low radical scavenging activity $(<50 \%)$, indicating that they have other mechanisms for inhibiting tyrosinase rather than scavenging reactive quinone products. For examples, they may be the competitive inhibitors such as copper chelators that inhibit this metalloenzyme or suicide inhibitors that inactivate tyrosinase by changing the tertiary and quaternary structures of the enzyme [54].

\subsection{Antifungal Activity}

The antifungal activity was determined using the fungal extracts of marine Trichoderma on Asteromyces cruciatus and Lindra thalassiae as target fungi. A. cruciatus is a ubiquitous marine fungus and has the ability to degrade alginate, which is the major material of the brown algal construct; therefore, it is regarded as a potentially harmful fungus to brown algae [55]. Lindra thalassiae is a well-known pathogen of brown algae and seagrasses and causes raisin disease [56]. In this study, eight strains showed remarkable growth inhibitory ability against both $A$. cruciatus and L. thalassiae: T. afroharzianum SFC20180619-M25, T. asperelloides SFC20180619-M20, T. asperellum SFC20160907-M21, SFC20180619-M22, and SFC20180619-M24, T. capillare SFC20160907-M2190, T. citrinoviride SFC20180510-M16 and T. virens SFC20180817-M24. T. asperellum SFC20160907-M21, SFC20180619-M22, and SFC20180619-M24 showed a high inhibitory effect against both target fungi (Table 2). In particular, T. asperellum SFC20160907-M21 and SFC20180619-M24 showed the highest inhibitory effect, as they could inhibit L. thalassiae at $6.25 \mu \mathrm{g} / \mathrm{mL}$. Since Trichoderma spp. are well known producers of antifungal compounds, such as 6-pentyl- $\alpha$-pyrone and trichodermaketones, it was expected that Trichoderma species could exhibit antagonistic ability against $A$. cruciatus and L. thalassiae, which are regarded as pathogenic fungi to algae $[25,26]$. Similarly, T. asperellum has already been investigated for its antagonistic ability against pathogenic fungi in several previous studies [57-59]. In addition, the synergistic effects of antifungal secondary metabolites and enzymes from Trichoderma could provide support to the plant rhizosphere attacked by other pathogenic fungi [21,27]. The results of this antifungal activity suggested that the antifungal compounds from Trichoderma could also support marine algae defense systems that are related to symbiosis, similar to the action of the plant rhizosphere. 
Table 2. Biological activities of the marine Trichoderma spp. extracts.

\begin{tabular}{|c|c|c|c|c|c|c|}
\hline \multirow{2}{*}{ Fungal Name } & \multirow{2}{*}{ ID } & \multicolumn{2}{|c|}{ Radical-Scavenging Activity (\%) } & \multicolumn{2}{|c|}{ Antifungal Activity $\left(\mathrm{MIC}^{3}, \mu \mathrm{g} / \mathrm{mL}\right)$} & \multirow{2}{*}{$\begin{array}{l}\text { Tyrosinase Inhibitior } \\
\quad\left(\mathrm{IC}_{50}{ }^{4}, \mu \mathrm{g} / \mathrm{mL}\right)\end{array}$} \\
\hline & & ABTS $^{1}$ & $\mathrm{DPPH}^{2}$ & L. thalassiae & A. cruciatus & \\
\hline \multirow[t]{3}{*}{ T. afroharzianum } & SFC20160907-M20 & 27.16 & 24.47 & N.D. & 100 & N.D. ${ }^{5}$ \\
\hline & SFC20190312-M15 & 69.92 & 25.29 & N.D. & $>100$ & N.D. \\
\hline & SFC20180619-M25 & 66.70 & 33.77 & $>100$ & $>100$ & N.D. \\
\hline T. asperelloides & SFC20180619-M20 & 47.70 & 41.06 & 50 & $>100$ & N.D. \\
\hline \multirow[t]{3}{*}{ T. asperellum } & SFC20160907-M21 & 73.38 & 30.62 & 6.25 & 50 & $>417$ \\
\hline & SFC20180619-M22 & 74.70 & 37.83 & $>100$ & 25 & $>417$ \\
\hline & SFC20180619-M24 & 72.63 & 32.34 & 6.25 & 25 & 104.23 \\
\hline \multirow{2}{*}{ T. atroviride } & SFC20161110-M05 & 32.18 & 38.03 & N.D. & N.D. & 15.30 \\
\hline & SFC20190312-M11 & 48.48 & 34.80 & N.D. & N.D. & $>417$ \\
\hline T. bissettii & SFC20170821-M05 & 57.17 & 79.60 & N.D. & $>100$ & $>417$ \\
\hline T. capillare & SFC20180619-M19 & 29.37 & 49.62 & $>100$ & $>100$ & N.D. \\
\hline T. citrinoviride & SFC20180510-M16 & 25.52 & 48.27 & $>100$ & $>100$ & N.D. \\
\hline T. gamsii & SFC20160907-M22 & 15.82 & 14.69 & N.D. & N.D. & 52.08 \\
\hline \multirow[t]{4}{*}{ T. guizhouense } & SFC20160907-M23 & 51.18 & 31.27 & N.D. & N.D. & N.D. \\
\hline & SFC20180619-M21 & 14.65 & 18.62 & $>100$ & N.D. & N.D. \\
\hline & SFC20180619-M23 & 18.17 & 23.41 & N.D. & N.D. & 7.28 \\
\hline & SFC20190312-M12 & 32.73 & 36.76 & N.D. & N.D. & 152.07 \\
\hline T. hamatum & SFC20180510-M09 & 23.29 & 35.33 & N.D. & N.D. & N.D. \\
\hline T. longibrachiatum & SFC20171019-M03 & 66.36 & 72.72 & N.D. & $>100$ & 252.26 \\
\hline T. orientalis & SFC20170718-M02 & 28.62 & 32.22 & N.D. & N.D. & N.D. \\
\hline T. paraviridescens & SFC20160907-M24 & 49.59 & 38.32 & N.D. & $>100$ & 118.61 \\
\hline T. pyramidale & SFC20160907-M25 & 25.02 & 2.36 & N.D. & $>100$ & N.D. \\
\hline T. songyi & SFC20171120-M04 & 27.14 & 14.60 & N.D. & N.D. & 23.77 \\
\hline T. subviride & SFC20170919-M07 & 61.71 & 53.43 & N.D. & N.D. & N.D. \\
\hline T. virens & SFC20180817-M24 & 42.20 & 45.53 & $>100$ & 100 & N.D. \\
\hline \multirow[t]{3}{*}{ Trichoderma sp. 1} & SFC20190312-M14 & 42.09 & 44.05 & N.D. & N.D. & N.D. \\
\hline & SFC20190312-M13 & 61.57 & 55.03 & $>100$ & N.D. & 119.74 \\
\hline & SFC20190312-M17 & 40.11 & 55.81 & $>100$ & N.D. & 148.1 \\
\hline Trichoderma sp. 2 & SFC20190312-M16 & 48.48 & 34.80 & N.D. & N.D. & N.D. \\
\hline Trichoderma sp. 3 & SFC20161110-M06 & 43.96 & 33.57 & N.D. & N.D. & N.D. \\
\hline Ascorbic acid * & & 13.70 & 6.80 & & & \\
\hline Kojic acid * & & & & & & 49.32 \\
\hline
\end{tabular}

${ }_{1}^{1} 2.2^{\prime}$-azino-bis-3-ethylbenzothiazoline-6-sulfonic acid; ${ }^{2}$ DPPH, 2,2-diphenyl-1-picrylhydrazyl; ${ }^{3}$ minimum inhibitory concentration; ${ }^{4}$ half maximal inhibitory concentration; ${ }^{5}$ not detected; * positive controls. 


\subsection{Tyrosinase Inhibition Activity}

Among the fungal extracts, 14 extracts showed tyrosinase inhibition activity (Table 2). Three strains of T. asperellum (SFC20160907-M21, SFC20180619-M22, and SFC20180619-M24) showed weak inhibitory activity. T. guizhouense SFC20180619-M23, T. atroviride SFC20161110-M05, and T. songyi SFC20171120-M04 exhibited the highest tyrosinase inhibitory effect. Interestingly, the extracts of T. guizhouense SFC20180619-M23, T. atroviride SFC20161110-M05, and T. songyi SFC20171120-M04 exhibited even higher activities than kojic acid, the most widely studied tyrosinase inhibitor from fungi. Kojic acid, which is produced by various species of Aspergillus and Penicillium, inhibits the formation of melanin and supports skin whitening [60-62]. Considering that the fungal extracts used in the experiments, unlike the single compound kojic acid, were crude extracts, these three Trichoderma species are expected to produce highly active tyrosinase inhibitors or produce multiple compounds with synergistic effects. In addition to kojic acid isolated from mushrooms, other tyrosinase inhibitors from fungi have been found recently, including $1 \beta, 5 \alpha, 6 \alpha, 14$-tetraacetoxy- $9 \alpha$-benzoyloxy-7 $\beta$ H-eudesman-2 $\beta, 11$-diol and $4 \alpha, 5 \alpha$-diacetoxy- $9 \alpha$-benzoyloxy-7 $\beta$ H-eudesman- $1 \beta, 2 \beta, 11,14$-tetraol [63]. Moreover, the novel tyrosinase inhibitor from marine Trichoderma was purified. The structure of the compound is the same as antibiotics from T. koningii and T. harzianum [64]. Many antibiotics and antioxidants also have potent tyrosinase inhibition activity, although the mechanism of various tyrosinase inhibitors is different [52]. In this study, the strains that exhibited high potent tyrosinase inhibition activity (T. guizhouense SFC20180619-M23, T. atroviride SFC20161110-M05, and T. songyi SFC20171120-M04) did not directly relate to the radical scavenging activities and antifungal activity. However, some strains that exhibited relatively weak tyrosinase inhibition activity showed radical scavenging activity and antifungal effects (T. asperellum SFC20160907-M21, SFC20180619-M22, and SFC20180619-M24; T. bissettii SFC20170821-M05; Trichoderma sp. 1 SFC20190312-M13; T. longibrachiatum SFC20171019-M03).

\section{Conclusions}

We investigated the diversity of marine-derived Trichoderma spp. and provided reliable DNA information of 30 marine Trichoderma species isolated in South Korea as well as their exploitable biological activities. Based on the phylogenetic analysis, the 30 marine Trichoderma species were classified into 21 taxa, including three new species candidates. Among them, three species-Trichoderma sp. 1, T. asperellum, and T. longibrachiatum-showed remarkable abilities in most of the biological activities investigated in this study. The potent bioactive compounds of these species will be studied in the near future. This study proved that marine-derived Trichoderma can be a useful source of bioactive compounds.

Author Contributions: Conceptualization, K.K., Y.M.H., and J.-J.K.; methodology, K.K., Y.M.H., S.J., and S.-L.K.; validation, H.L., Y.W.L., and J.-J.K.; resources, S.-L.K., M.S.P., and Y.W.L.; writing-original draft preparation, K.K., Y.M.H., and S.J.; writing-review and editing, H.L., M.S.P., Y.W.L., and J.-J.K.; visualization, K.K., Y.M.H., and H.L.; supervision, J.-J.K.; project administration, J.-J.K.; funding acquisition, J.-J.K. All authors have read and agreed to the published version of the manuscript.

Funding: This research was funded by the project on survey and excavation of Korean indigenous species of National Institute of Biological Resources (NIBR201902113) under the Ministry of Environment, Republic of Korea. This study was also funded by a Korea University Grant and the Ministry of Oceans and Fisheries (MOF) [20170325].

Conflicts of Interest: The authors declare no conflict of interest.

\section{References}

1. Freguia, S.; Logrieco, M.E.; Monetti, J.; Ledezma, P.; Virdis, B.; Tsujimura, S. Self-powered bioelectrochemical nutrient recovery for fertilizer generation from human urine. Sustainability 2019, 11, 5490. [CrossRef] 
2. Chou, J.-S.; Yu, C.-P.; Truong, D.-N.; Susilo, B.; Hu, A.; Sun, Q. Predicting microbial species in a river based on physicochemical properties by bio-inspired metaheuristic optimized machine learning. Sustainability 2019, 11, 6889. [CrossRef]

3. Vieira, T.A.; Panagopoulos, T. Urban forestry in brazilian amazonia. Sustainability 2020, 12, 3235. [CrossRef]

4. Heo, Y.M.; Lee, H.; Kim, K.; Kwon, S.L.; Park, M.Y.; Kang, J.E.; Kim, G.-H.; Kim, B.S.; Kim, J.-J. Fungal diversity in intertidal mudflats and abandoned solar salterns as a source for biological resources. Mar. Drugs 2019, 17, 601. [CrossRef] [PubMed]

5. Lee, H.; Lee, D.W.; Kwon, S.L.; Heo, Y.M.; Jang, S.; Kwon, B.-O.; Khim, J.S.; Kim, G.-H.; Kim, J.-J. Importance of functional diversity in assessing the recovery of the microbial community after the hebei spirit oil spill in korea. Environ. Int. 2019, 128, 89-94. [CrossRef] [PubMed]

6. Lee, H.; Heo, Y.M.; Kwon, S.L.; Yoo, Y.; Lee, A.H.; Kwon, B.-O.; Kim, G.-H.; Khim, J.S.; Kim, J.-J. Recovery of the benthic bacterial community in coastal abandoned saltern requires over 35 years: A comparative case study in the yellow sea. Environ. Int. 2020, 135, 105412. [CrossRef]

7. Romano, G.; Costantini, M.; Sansone, C.; Lauritano, C.; Ruocco, N.; Ianora, A. Marine microorganisms as a promising and sustainable source of bioactive molecules. Mar. Environ. Res. 2017, 128, 58-69. [CrossRef]

8. Tourova, T.; Sokolova, D.; Nazina, T.; Grouzdev, D.; Kurshev, E.; Laptev, A. Biodiversity of microorganisms colonizing the surface of polystyrene samples exposed to different aqueous environments. Sustainability 2020, 12, 3624. [CrossRef]

9. Ge, S.; Ma, J.; Liu, L.; Yuan, Z. The impact of exogenous aerobic bacteria on sustainable methane production associated with municipal solid waste biodegradation: Revealed by high-throughput sequencing. Sustainability 2020, 12, 1815. [CrossRef]

10. Han, S.-I.; Jeon, M.S.; Heo, Y.M.; Kim, S.; Choi, Y.-E. Effect of pseudoalteromonas sp. Mebic 03485 on biomass production and sulfated polysaccharide biosynthesis in porphyridium cruentum utex 161. Bioresour. Technol. 2020, 302, 122791. [CrossRef]

11. Ham, J.; Lim, W.; Kim, K.; Heo, Y.M.; Ryu, S.M.; Lee, D.; Kim, J.-J.; Song, G. Gentisyl alcohol inhibits proliferation and induces apoptosis via mitochondrial dysfunction and regulation of mapk and pi3k/akt pathways in epithelial ovarian cancer cells. Mar. Drugs 2019, 17, 331. [CrossRef] [PubMed]

12. Heo, Y.M.; Lee, H.; Lee, C.; Kang, J.; Ahn, J.-W.; Lee, Y.M.; Kang, K.-Y.; Choi, Y.-E.; Kim, J.-J. An integrative process for obtaining lipids and glucose from chlorella vulgaris biomass with a single treatment of cell disruption. Algal Res.-Biomass Biofuels Bioprod. 2017, 27, 286-294. [CrossRef]

13. Heo, Y.M.; Kim, K.; Kwon, S.L.; Na, J.; Lee, H.; Jang, S.; Kim, C.H.; Jung, J.; Kim, J.-J. Investigation of filamentous fungi producing safe, functional water-soluble pigments. Mycobiology 2018, 46, 269-277. [CrossRef] [PubMed]

14. Lee, H.; Lee, Y.M.; Heo, Y.M.; Lee, J.; Kim, J.S.; Kang, K.Y.; Kim, J.-J. Utilization of agricultural residues for enhancement of cellulolytic enzyme production and enzymatic saccharification by trichoderma harzianum kuc1716. Ind. Crops Prod. 2017, 109, 185-191. [CrossRef]

15. Newman, D.J.; Cragg, G.M. Marine natural products and related compounds in clinical and advanced preclinical trials. J. Nat. Prod. 2004, 67, 1216-1238. [CrossRef]

16. Newman, D.J.; Cragg, G.M. Natural products as sources of new drugs over the last 25 years. J. Nat. Prod. 2007, 70, 461-477. [CrossRef]

17. Agrawal, S.; Adholeya, A.; Barrow, C.J.; Deshmukh, S.K. Marine fungi: An untapped bioresource for future cosmeceuticals. Phytochem. Lett. 2018, 23, 15-20. [CrossRef]

18. Molinski, T.F.; Dalisay, D.S.; Lievens, S.L.; Saludes, J.P. Drug development from marine natural products. Nat. Rev. Drug Discov. 2009, 8, 69. [CrossRef]

19. Troussellier, M.; Escalas, A.; Bouvier, T.; Mouillot, D. Sustaining rare marine microorganisms: Macroorganisms as repositories and dispersal agents of microbial diversity. Front. Microbiol. 2017, 8, 947. [CrossRef]

20. Kong, Q. Marine microorganisms as biocontrol agents against fungal phytopathogens and mycotoxins. Biocontrol Sci. Technol. 2018, 28, 77-93. [CrossRef]

21. Druzhinina, I.S.; Seidl-Seiboth, V.; Herrera-Estrella, A.; Horwitz, B.A.; Kenerley, C.M.; Monte, E.; Mukherjee, P.K.; Zeilinger, S.; Grigoriev, I.V.; Kubicek, C.P. Trichoderma: The genomics of opportunistic success. Nat. Rev. Microbiol. 2011, 9, 749. [CrossRef] [PubMed]

22. Sivasithamparam, K.; Ghisalberti, E. Secondary metabolism in trichoderma. Trichoderma Gliocladium. Vol. 1 Basic Biol. Taxon. Genet. 2014, 1, 139. 
23. Lu, Z.; Tombolini, R.; Woo, S.; Zeilinger, S.; Lorito, M.; Jansson, J.K. In vivo study of trichoderma-pathogen-plant interactions, using constitutive and inducible green fluorescent protein reporter systems. Appl. Environ. Microbiol. 2004, 70, 3073-3081. [CrossRef] [PubMed]

24. Reino, J.L.; Guerrero, R.F.; Hernández-Galán, R.; Collado, I.G. Secondary metabolites from species of the biocontrol agent trichoderma. Phytochem. Rev. 2008, 7, 89-123. [CrossRef]

25. Hong, J.-H.; Lee, J.; Min, M.; Ryu, S.-M.; Lee, D.; Kim, G.-H.; Kim, J.-J. 6-pentyl- $\alpha$-pyrone as an anti-sapstain compound produced by trichoderma gamsii kuc1747 inhibits the germination of ophiostomatoid fungi. Holzforschung 2014, 68, 769-774. [CrossRef]

26. Song, F.; Dai, H.; Tong, Y.; Ren, B.; Chen, C.; Sun, N.; Liu, X.; Bian, J.; Liu, M.; Gao, H.; et al. Trichodermaketones a-d and 7-o-methylkoninginin d from the marine fungus trichoderma koningii. J. Nat. Prod. 2010, 73, 806-810. [CrossRef]

27. Harman, G.E.; Howell, C.R.; Viterbo, A.; Chet, I.; Lorito, M. Trichoderma species-Opportunistic, avirulent plant symbionts. Nat. Rev. Microbiol. 2004, 2, 43. [CrossRef]

28. Bissett, J.; Gams, W.; Jaklitsch, W.; Samuels, G.J. Accepted trichoderma names in the year 2015. IMA Fungus 2015, 6, 263-295. [CrossRef]

29. Su, D.; Ding, L.; He, S. Marine-derived trichoderma species as a promising source of bioactive secondary metabolites. Mini-Rev. Med. Chem. 2018, 18, 1702-1713. [CrossRef]

30. Zhang, J.-C.; Chen, G.-Y.; Li, X.-Z.; Hu, M.; Wang, B.-Y.; Ruan, B.-H.; Zhou, H.; Zhao, L.-X.; Zhou, J.; Ding, Z.-T. Phytotoxic, antibacterial, and antioxidant activities of mycotoxins and other metabolites from trichoderma sp. Nat. Prod. Res. 2017, 31, 2745-2752. [CrossRef]

31. Samson, R.A.; Hoekstra, E.S.; Frisvad, J.C. Introduction to Food-and Airborne Fungi; Centraalbureau Voor Schimmelcultures (CBS): New York, NY, USA, 2004.

32. Chaverri, P.; Branco-Rocha, F.; Jaklitsch, W.; Gazis, R.; Degenkolb, T.; Samuels, G.J. Systematics of the trichoderma harzianum species complex and the re-identification of commercial biocontrol strains. Mycologia 2015, 107, 558-590. [CrossRef] [PubMed]

33. Lind, A.L.; Wisecaver, J.H.; Lameiras, C.; Wiemann, P.; Palmer, J.M.; Keller, N.P.; Rodrigues, F.; Goldman, G.H.; Rokas, A. Drivers of genetic diversity in secondary metabolic gene clusters within a fungal species. PLoS Biol. 2017, 15, e2003583. [CrossRef] [PubMed]

34. Samuels, G.J.; Dodd, S.L.; Gams, W.; Castlebury, L.A.; Petrini, O. Trichoderma species associated with the green mold epidemic of commercially grown agaricus bisporus. Mycologia 2002, 94, 146-170. [CrossRef] [PubMed]

35. White, T.J.; Bruns, T.; Lee, S.; Taylor, J. Amplification and direct sequencing of fungal ribosomal rna genes for phylogenetics. PCR Protoc. A Guide Methods Appl. 1990, 18, 315-322.

36. Schoch, C.L.; Seifert, K.A.; Huhndorf, S.; Robert, V.; Spouge, J.L.; Levesque, C.A.; Chen, W.; Bolchacova, E.; Voigt, K.; Crous, P.W.; et al. Nuclear ribosomal internal transcribed spacer (its) region as a universal DNA barcode marker for fungi. Proc. Natl. Acad. Sci. USA 2012, 109, 6241-6246. [CrossRef] [PubMed]

37. Katoh, K.; Standley, D.M. Mafft multiple sequence alignment software version 7: Improvements in performance and usability. Mol. Biol. Evol. 2013, 30, 772-780. [CrossRef]

38. Maddison, D.R.; Maddison, W.P. Macclade 4; Sinauer: Sunderland, MA, USA, 2000.

39. Swofford, D.L. Phylogenetic Analysis Using Parsimony; Illinois Natural History Survey: Champaign, IL, USA, 1993.

40. Kimura, M. A simple method for estimating evolutionary rates of base substitutions through comparative studies of nucleotide-sequences. J. Mol. Evol. 1980, 16, 111-120. [CrossRef]

41. Hafidh, R.R.; Abdulamir, A.S.; Vern, L.S.; Bakar, F.A.; Abas, F.; Jahanshiri, F.; Sekawi, Z. Inhibition of growth of highly resistant bacterial and fungal pathogens by a natural product. Open Microbiol. J. 2011, 5, 96. [CrossRef]

42. Lai, H.Y.; Lim, Y.Y.; Tan, S.P. Antioxidative, tyrosinase inhibiting and antibacterial activities of leaf extracts from medicinal ferns. Biosci. Biotechnol. Biochem. 2009, 73, 1362-1366. [CrossRef]

43. Zhu, Z.; Zhuang, W. Trichoderma (hypocrea) species with green ascospores from china. Pers. Mol. Phylogeny Evol. Fungi 2015, 34, 113. [CrossRef]

44. Samuels, G.J.; Ismaiel, A.; Mulaw, T.B.; Szakacs, G.; Druzhinina, I.S.; Kubicek, C.P.; Jaklitsch, W.M. The longibrachiatum clade of trichoderma: A revision with new species. Fungal Divers. 2012, 55, 77-108. [CrossRef] [PubMed] 
45. Sandoval-Denis, M.; Sutton, D.A.; Cano-Lira, J.F.; Gené, J.; Fothergill, A.W.; Wiederhold, N.P.; Guarro, J. Phylogeny of the clinically relevant species of the emerging fungus trichoderma and their antifungal susceptibilities. J. Clin. Microbiol. 2014, 52, 2112-2125. [CrossRef] [PubMed]

46. Jaklitsch, W.; Samuels, G.; Ismaiel, A.; Voglmayr, H. Disentangling the trichoderma viridescens complex. Pers. Mol. Phylogeny Evol. Fungi 2013, 31, 112. [CrossRef] [PubMed]

47. Jaklitsch, W.M. European species of hypocrea part ii: Species with hyaline ascospores. Fungal Divers. 2011, 48, 1-250. [CrossRef]

48. Park, M.S.; Oh, S.-Y.; Cho, H.J.; Fong, J.J.; Cheon, W.-J.; Lim, Y.W. Trichoderma songyi sp. Nov., a new species associated with the pine mushroom (tricholoma matsutake). Antonie Van Leeuwenhoek 2014, 106, 593-603. [CrossRef]

49. Ze-Hong, W.; Dong, L.; Ying, X.; Jian-Liang, C.; Wen-Han, L. Antioxidant xanthones and anthraquinones isolated from a marine-derived fungus aspergillus versicolor. Chin. J. Nat. Med. 2018, 16, $219-224$.

50. Gogineni, V.; Hamann, M.T. Marine natural product peptides with therapeutic potential: Chemistry, biosynthesis, and pharmacology. Biochim. Biophys. Acta 2018, 1862, 81-196. [CrossRef]

51. Douglas, T.E.; Dokupil, A.; Reczyńska, K.; Brackman, G.; Krok-Borkowicz, M.; Keppler, J.K.; Božič, M.; Van Der Voort, P.; Pietryga, K.; Samal, S.K. Enrichment of enzymatically mineralized gellan gum hydrogels with phlorotannin-rich ecklonia cava extract seanol@to endow antibacterial properties and promote mineralization. Biomed. Mater. 2016, 11, 045015. [CrossRef]

52. Chang, T.-S. An updated review of tyrosinase inhibitors. Int. J. Mol. Sci. 2009, 10, 2440-2475. [CrossRef]

53. Mas-Chamberlin, C.; Mondon, P.; Lamy, F.; Peschard, O.; Lintner, K. Strategies of antiaging actives in sunscreen products. Cosmet. Toilet. 2006, 121, 45.

54. Zolghadri, S.; Bahrami, A.; Hassan Khan, M.T.; Munoz-Munoz, J.; Garcia-Molina, F.; Garcia-Canovas, F.; Saboury, A.A. A comprehensive review on tyrosinase inhibitors. J. Enzyme Inhib. Med. Chem. 2019, 34, 279-309. [CrossRef] [PubMed]

55. Heo, Y.M.; Kim, K.; Ryu, S.M.; Kwon, S.L.; Park, M.Y.; Kang, J.E.; Hong, J.-H.; Lim, Y.W.; Kim, C.; Kim, B.S.; et al. Diversity and ecology of marine algicolous arthrinium species as a source of bioactive natural products. Mar. Drugs 2018, 16, 508. [CrossRef] [PubMed]

56. Porter, D. 13 mycoses of marine organisms: An overview of pathogenic fungi. In The Biology of Marine Fungi; Cambridge University Press: Cambridge, UK, 1986; ISBN 13: 978-0521308991.

57. Skaptsov, M.; Smirnov, S.; Kutsev, M.; Uvarova, O.; Sinitsyna, T.; Shmakov, A.; Matsura, A. Antifungal activity of several isolates of trichoderma against cladosporium and botrytis. Ukr. J. Ecol. 2018, 8, 88-91. [CrossRef]

58. Vinodkumar, S.; Indumathi, T.; Nakkeeran, S. Trichoderma asperellum (nvta2) as a potential antagonist for the management of stem rot in carnation under protected cultivation. Biol. Control 2017, 113, 58-64. [CrossRef]

59. Wu, Q.; Sun, R.; Ni, M.; Yu, J.; Li, Y.; Yu, C.; Dou, K.; Ren, J.; Chen, J. Identification of a novel fungus, trichoderma asperellum gdfs1009, and comprehensive evaluation of its biocontrol efficacy. PLoS ONE 2017, 12, e0179957. [CrossRef] [PubMed]

60. Chen, J.S.; Wei, C.I.; Marshall, M.R. Inhibition mechanism of kojic acid on polyphenol oxidase. J. Agric. Food Chem. 1991, 39, 1897-1901. [CrossRef]

61. May, O.; Moyer, A.; Wells, P.; Herrick, H. The production of kojic acid by aspergillus flavus. J. Am. Chem. Soc. 1931, 53, 774-782. [CrossRef]

62. Parrish, F.; Wiley, B.; Simmons, E.; Long Jr, L. Production of aflatoxins and kojic acid by species of aspergillus and penicillium. Appl. Microbiol. 1966, 14, 139. [CrossRef]

63. Wu, B.; Wu, X.; Sun, M.; Li, M. Two novel tyrosinase inhibitory sesquiterpenes induced by $\mathrm{Cucl}_{2}$ from a marine-derived fungus pestalotiopsis sp. Z233. Mar. Drugs 2013, 11, 2713-2721. [CrossRef]

64. Tsuchiya, T.; Yamada, K.; Minoura, K.; Miyamoto, K.; Usami, Y.; Kobayashi, T.; Hamada-Sato, N.; Imada, C.; Tsujibo, H. Purification and determination of the chemical structure of the tyrosinase inhibitor produced by trichoderma viride strain h1-7 from a marine environment. Biol. Pharm. Bull. 2008, 31, 1618-1620. [CrossRef] 